\title{
Biopreservation of Fior di Latte cheese
}

\author{
L. Angiolillo, ${ }^{*}$ A. Conte, ${ }^{*}$ A. V. Zambrini, $†$ and M. A. Del Nobile*1 \\ *Department of Agricultural Sciences, Food and Environment, University of Foggia, Via Napoli, 25 - 71121 Foggia, Italy \\ †Department of Quality, Innovation, Safety, Environment, Granarolo S.p.A., via Cadriano 27/2, 43036 Bologna, Italy
}

\section{ABSTRACT}

In this study a new biopreservation system consisting of an active sodium alginate coating containing Lactobacillus reuteri applied to Fior di Latte cheese was studied. The final aim was to extend cheese shelf life by the in situ production of reuterin. Experimental trials were carried out with and without glycerol. How the fermentation time could improve the production of reuterin, enabling Fior di Latte shelf life, was also assessed. To this aim, the experimental analyses were conducted in 2 different trials, using 2 different production batches of samples. In the first one, Fior di Latte samples were dipped into the active sodium alginate solution prepared on the same day of their production, whereas in the second trial, samples were dipped into the active solution prepared $48 \mathrm{~h}$ before their production to allow a proper fermentation of the inoculated microorganism. Microbiological and sensory quality indices were monitored to prove the effectiveness of biopreservation on product quality during storage. In the first trial, the combination of the probiotic microorganism with glycerol improved the microbial quality by $1 \mathrm{~d}$ compared with the same active solution without glycerol, whereas the 48-h-fermented active alginate solution (second trial) showed a further improved microbial quality. The application of an active coating enriched with $L$. reuteri and glycerol to Fior di Latte cheese is an optimal and innovative way to preserve the product and at the same time, with a combination of an optimal fermentation time, to prolong its microbial quality and thus its shelf life.

Key words: biopreservation, Fior di Latte

\section{INTRODUCTION}

Fior di Latte cheese is a typical Mediterranean fresh pasta filata product, made from cow milk and usually packaged in brine. It has high moisture content (from 55 to $64 \%$ ) and high fat content ( $>45 \%$ fat in DM; Salvadori del Prato, 2001), so it is very susceptible to

Received February 6, 2014.

Accepted April 27, 2014.

${ }^{1}$ Corresponding author: ma.delnobile@unifg.it microbial spoilage, especially under temperature abuse. Although milk is submitted to a further heat treatment during curd stretching to produce Fior di Latte, postprocessing contamination may occur, causing cheese spoilage and eventually safety risks to consumers (Spano et al., 2003). Undesirable microorganisms such as pseudomonads, coliforms, yeasts, and molds may cause defects in flavor, texture, and appearance and result in economic losses (Gammariello et al., 2008; Conte et al., 2009; Del Nobile et al., 2009). Fior di Latte shelf life also depends on the quality of raw material and on the process conditions (Brody, 2001).

Current technologies for preservation and shelf-life extension of food include heat processing, chemical preservatives, modified-atmosphere packaging, or refrigeration. Unfortunately, these strategies do not fully control spoilage bacteria. The great availability of nutrients in foods may enable bacteria to repair damaged cells (Gill et al., 2002). Both the intrinsic (fat, protein, water content, antioxidants, $\mathrm{pH}$, salt, and other additives) and the extrinsic properties (temperature; packaging in vacuum, gas, or air; characteristics of microorganisms) of the food can influence bacterial sensitivity to natural and chemical preservatives (Shelef, 1983; Tassau et al., 2000). At present, Fior di Latte cheese shelf life is approximately 5 to $7 \mathrm{~d}$, and many efforts are in progress to prolong this shelf life by means of process innovation and quality improvement of raw materials. Good opportunities came from the use of antimicrobial compounds during milk transformation (Del Nobile et al., 2009). The high consumer attention to food-safety aspects justifies increased research interest in using active agents derived from natural sources, as plant essential oils or plant extracts, considered suitable for food application, able to reduce the microbial count and to control the cell growth during the different steps of the product life (Conte et al., 2007; Gammariello et al., 2008b, 2010). Efforts to prolong the shelf life of Fior di Latte cheese are also made by the optimization of storage and packaging conditions (Conte et al., 2009; Del Nobile et al., 2009, 2010). The potential of modified-atmosphere packaging and active packaging to extend the shelf life of different dairy products has been proposed by various authors (Floros et al., 2000; Pantaleao et al., 2007; Papaioannou et al., 2007). 
The great demand for fresh-like products still promotes the search for new technologies to preserve food. One of the most recent potential approaches to prolong the shelf life of fresh products is the use of biopreservation systems. Biopreservation is the use of natural or controlled microbiota or antimicrobials as a way of preserving food and extending its shelf life (Ananouet al., 2007). Beneficial bacteria or their fermentation products are used in biopreservation to control spoilage and render pathogens inactive in food (Yousef and Carlstrom, 2003). Lactic acid bacteria (LAB) have antagonistic properties that make them particularly useful as biopreservatives. When LAB compete for nutrients, their metabolites often include active antimicrobials such as lactic and acetic acid, hydrogen peroxide, and peptide bacteriocins. Biopreservative bacteria must be harmless to humans. Lactic acid bacteria bacteriocins are used as an integral part of hurdle technology. Using them in combination with other preservative techniques can effectively control spoilage bacteria and other pathogens and can inhibit the activities of a wide spectrum of organisms, including inherently resistant gram-negative bacteria. Angiolillo et al. (2013) stated that the addition of Lactobacillus rhamnosus in an edible sodium alginate coating applied on the surface of Fior di Latte cheese exerted an antimicrobial activity against Pseudomonas spp. and Enterobacteriaceae.

Lactobacillus reuteri is a heterofermentative lactobacillus recognized as a normal inhabitant of the human and animal gut (Reuter, 2001). It is also frequently found in fermented and probiotic foods (Vollenweider and Lacroix, 2004). Lactobacillus reuteri as a food supplement is accepted and widely used to improve gastrointestinal health and has been granted qualified presumption of safety by the European Food Safety Authority. Probiotic effects of $L$. reuteri have been proposed due to the ability of some strains to produce reuterin (3-hydroxypropionaldehyde) during anaerobic metabolism of glycerol (Rodríguez et al., 2003). Reuterin is an antimicrobial compound soluble in water, resistant to heat, and stable over a wide range of $\mathrm{pH}$ values, that inactivates gram-negative and gram-positive bacteria (Vollenweider et al., 2003). Direct addition of reuterin to control food-borne pathogens such Salmonella spp., Escherichia coli O157:H7, Listeria monocytogenes, and Staphylococcus aureus has been investigated in milk and dairy products (Arqués et al., 2008a,b), but the gap of these studies consisted of the fact that reuterin was used as a food additive. In this study, we tried to overcome this limit by developing a new biopreservation system consisting of a sodium alginate coating containing $L$. reuteri in combination with glycerol (registered in the European Union as food additive E 422), applied on the surface of Fior di Latte cheese to extend its shelf life by means of in situ production of reuterin. Experimental trials were carried out with and without glycerol. We also studied how the fermentation time could improve the production of reuterin, enabling Fior di Latte shelf life. Microbiological and sensory quality indices were monitored to prove the effectiveness of biopreservation on product quality during storage.

\section{MATERIALS AND METHODS}

\section{Sample Preparation}

Fior di Latte samples were purchased from a local cheese factory Capurso Azienda Casearia SPA (Gioia del Colle, Bari, Italy) and transported to the laboratory in polystyrene boxes containing ice. The cheese was made from pasteurized cow milk by adding lactic acid bacteria as starters. The curd was obtained after the coagulation of milk by rennet and after a curdripening phase $\left(4.0\right.$ to $4.5 \mathrm{~h}$ at 35 to $37^{\circ} \mathrm{C}$ ); when the optimal pH (4.9 to 5.4) was reached, the drained curd was stretched in hot water $\left(90\right.$ to $\left.95^{\circ} \mathrm{C}\right)$.

Once transported to the laboratory, the samples were dipped into 3 different sodium alginate solutions. The first one was prepared by dissolving sodium alginate acid (Farmalabor, Canosa di Puglia, Italy; 2\% wt/ vol) in distilled water; the second one was prepared by dissolving sodium alginate acid $(2 \% \mathrm{wt} / \mathrm{vol})$ in a solution made of $2 \%$ (wt/vol) of pure freeze-dried $L$. reuteri (Granarolo, Bologna, Italy) and distilled water; and the third solution was made of $2 \%$ (wt/vol) of pure freeze-dried L. reuteri (Granarolo), $0.6 \%$ of glycerol (Sigma-Aldrich, Milan, Italy), and distilled water. The coated samples were immersed in a $5 \%$ (wt/vol) calcium chloride $\left(\mathrm{CaCl}_{2}\right.$; Sigma-Aldrich) for $1 \mathrm{~min}$, to allowed creating a stable coating on the cheese surface. All samples were dried at room temperature for $2 \mathrm{~min}$ and packaged in commercially available polypropylene bags with brine ( $0.2 \% \mathrm{wt} / \mathrm{vol}$ of $\mathrm{NaCl}$ solution). The control samples consisted of Fior di Latte cheese without coating, packaged in trays with brine. All the samples were stored at $9^{\circ} \mathrm{C}$. The experimental analyses were conducted in 2 different trials, using 2 different production batches of samples. In the first trial, Fior di Latte samples were dipped into the sodium alginate solutions prepared on the same day of their production, whereas in the second trial, samples were dipped in sodium alginate solutions prepared $48 \mathrm{~h}$ before their production. Sodium alginate solutions used in the second trial were prepared in bottles with hermetic seals to avoid evaporation. Immediately after their preparation, sodium alginate solutions were incubated at $25^{\circ} \mathrm{C}$ for $48 \mathrm{~h}$. Samples will be named as follows: CNT (control sample consisting of Fior di Latte cheese without coat- 
ing), COAT (Fior di Latte cheese with a $2 \%$ sodium alginate coating without $L$. reuteri), ACT-COAT (Fior di Latte cheese with a $2 \%$ sodium alginate coating containing L. reuteri), and ACT-COAT-GLY (Fior di Latte cheese with a $2 \%$ sodium alginate coating containing $L$. reuteri and glycerol). The sampling was performed immediately after the production and subsequently every day at the same time for a week.

\section{Microbiological Analyses}

Twenty grams of Fior di Latte was aseptically removed from each package, diluted with $180 \mathrm{~mL}$ of $\mathrm{NaCl}$ solution $0.9 \%$ in a stomacher bag, and homogenized with a Stomacher LAB Blender 400 (Pbi International, Milan, Italy). Subsequently, decimal dilutions of homogenates were made using the same diluent, and the dilutions were plated on appropriate media in Petri dishes. Enterobacteriaceae were determined on violet red bile glucose agar (Oxoid S.p.A., Rodano, Italy) after incubation at $37^{\circ} \mathrm{C}$ for 18 to $24 \mathrm{~h}$. Pseudomonas agar base (Oxoid) was added with SR103 E selective supplement (Oxoid) and incubated at $25^{\circ} \mathrm{C}$ for $48 \mathrm{~h}$ for Pseudomonas spp. All analyses were performed in duplicate on 2 different samples. To quantitatively determine the microbial acceptability limit, a modified version of the Gompertz equation was fitted to the experimental data, as reported in previous works (Conte et al., 2009; Del Nobile et al., 2009).

$$
\begin{aligned}
& \log [N(t)]=\log \left(N_{\max }\right) \\
& -A \cdot \exp \left(-\exp \left\{\left[\left(\mu_{\max } \cdot 2.71\right) \cdot \frac{\lambda-\mathrm{MAL}}{A}\right]+1\right\}\right) \\
& +A \cdot \exp \left(-\exp \left\{\left[\left(\mu_{\max } \cdot 2.71\right) \cdot \frac{\lambda-t}{A}\right]+1\right\}\right),
\end{aligned}
$$

where $N(t)$ is the viable cell concentration at time $t, A$ is related to the difference between the decimal logarithm of maximum bacterial growth attained at the stationary phase and decimal logarithm of the initial value of cell concentration, $\mu_{\max }$ is the maximal specific growth rate, $\lambda$ is the lag time, $N_{\max }$ is the microbial threshold value, MAL is the microbiological acceptability limit [i.e., the time when $N(t)$ is equal to $N_{\max }$ ], and $t$ is the storage time. The value of $N_{\max }$ for Pseudomonas spp. was set to $10^{6} \mathrm{cfu} / \mathrm{g}$ of cheese and $10^{5} \mathrm{cfu} / \mathrm{g}$ for Enterobacteriaceae (MAL ${ }^{\text {Enterobacteriaceae }}$ ) according to other works dealing with the same dairy product (Conte et al., 2009).

\section{Sensory Analysis}

Sensory analysis was conducted according to a method reported in the literature (Chiavari et al.,
2006). A quantitative descriptive analysis was used for the comparison of samples (UNI 10957:2003 Sensory analysis - Method to define the sensory profile of foods and beverages, UNI, 2003).

In accordance with the standard UNI 10957:2003 (UNI, 2003), 8 testers of the Food Packaging laboratory were selected on the basis of international standards ISO 8586-1:1993 (ISO, 1993) and ISO 8586-2:1994 (ISO, 1994). Nine sessions of $1 \mathrm{~h}$ each were required to define the sensory profile, with the frequency of 3 meetings a week. The sessions were used to familiarize the testers with the characteristics of Fior di Latte samples in terms of odor, color, texture and overall quality. After training, Fior di Latte samples were presented to each panelist without brine (Angiolillo et al., 2013). The panelist was asked to evaluate odor, color, texture, and overall quality every day for the entire period of observation, by using a scale from 0 to 7 , where 4 was the minimum threshold for cheese acceptability. To judge the overall quality of cheese, the following product characteristics were also taken into account: white porcelain, smooth surface, tight shut-off, elastic release of buttermilk after cutting, lack of holes, and typical milk smell. The analysis of the texture was performed by touching the surface of the products with fingers and evaluating the degree of surface fraying with movements from top to bottom of the surface. Each taster evaluated a set of 4 samples each labeled with a random 3-digit code. Samples had been stored in the sensory analysis laboratory at room temperature before tasting, and the order of presentation was different for each accepted subject, to avoid mutual interference. Before evaluating, each coated Fior di Latte cheese was deprived of the coating and immersed in water at room temperature for a few minutes, to tie these samples to wet uncoated cheese. The tasters used individual tasting booths in the hall of sensory analysis of the Food Packaging laboratory. The quantitative analysis was performed with a number equal to 3 replicates sessions on different days at the same hour of each day. To determine the sensory acceptability limit (SAL), that represents the storage time to reach the sensory attribute threshold, a modified version of the Gompertz equation was fitted to the experimental data (Conte et al., 2009; Del Nobile et al., 2009).

$$
\begin{aligned}
& \mathrm{SA}(t)=\mathrm{SA}_{\min }-A^{\mathrm{SA}} \\
& \cdot \exp \left(-\exp \left\{\left[\left(\mu_{\max }^{\mathrm{SA}} \cdot 2.71\right) \cdot \frac{\lambda^{\mathrm{SA}}-\mathrm{SAL}}{A^{Q}}\right]+1\right\}\right) \\
& +A^{\mathrm{SA}} \cdot \exp \left(-\exp \left\{\left[\left(\mu_{\max }^{\mathrm{SA}} \cdot 2.71\right) \cdot \frac{\lambda^{\mathrm{SA}}-t}{A^{\mathrm{SA}}}\right]+1\right\}\right),
\end{aligned}
$$


where $\mathrm{SA}(t)$ is the sensory attribute at time $t, \mathrm{SA}_{\min }$ is the sensory attribute threshold value, $A$ is related to the difference between the sensory attribute attained at the stationary phase and the initial value of sensory attribute, $\mu_{\max }$ is the maximal rate at which $\mathrm{SA}(t)$ decreases, $\lambda$ is the lag time, SAL is the sensory acceptability limit [i.e., the time at which $\mathrm{SA}(t)$ is equal to $\left.\mathrm{SA}_{\min }\right]$, and $t$ is the storage time. As reported above, the value of $\mathrm{SA}_{\min }$ was set equal to 4 .

\section{Statistical Analysis}

Data from fitting procedure were compared by oneway ANOVA analysis. A Duncan's multiple range test, with the option of homogeneous groups $(P<0.05)$, was used to determine significance among differences. To this aim, Statistica 7.1 for Windows 152 (StatSoft Inc., Tulsa, OK) was used.

\section{RESULTS AND DISCUSSION}

As reported above, the biopreservation was adopted to preserve the microbiological and sensory quality of Fior di Latte cheese. In particular, the system consisted in the application of 2 kinds of active coatings on the product surface: the first containing $L$. reuteri and the second containing the microorganism plus glycerol. Furthermore, these active solutions were applied to cheese in 2 different ways: without any microorganism fermentation (first trial) and after $48 \mathrm{~h}$ of microorganism fermentation (second trial). This technological strategy was chosen because it has been demonstrated that $L$. reuteri produces the reuterin as an intermediate metabolite during the anaerobic fermentation of glycerol (Rasch et al., 2002). To prove the effectiveness of the treatments, microbial and sensory attributes were monitored. In the following, results obtained were reported and discussed separately.

\section{Microbiological Quality}

Figure 1 shows the evolution of Pseudomonas spp. count in Fior di Latte cheese during the 2 experimental trials: without fermentation of the sodium alginic solution (a) and after $48 \mathrm{~h}$ of microbial fermentation (b). Bishop and White (1986) stated that a Pseudomonas spp. microbial load equal to $10^{6} \mathrm{cfu} / \mathrm{g}$ of cheese represents the contamination level at which the alterations of the product start to appear. As it can be seen in the Figure 1(a), microbial count immediately increased for COAT sample, whereas the microbial population for CNT and ACT-COAT samples started to grow $1 \mathrm{~d}$ later and in the case of ACT-COAT-GLY, $2 \mathrm{~d}$ later. The COAT and CNT samples reached the mi- crobiological acceptability limit $\left(\mathrm{MAL}^{\text {Pseudomonas }}\right)$ at $\mathrm{d}$ 3.3 and 3.5, respectively, and so, faster than the other 2 active samples ACT-COAT and ACT-COAT-GLY that matched the limit at $\mathrm{d} 4.3$ and 5, respectively. In Figure 1(b) the precedent findings were confirmed and emphasized, in fact as in the first trial, COAT and CNT samples were the first ones started to grow and to reach the microbial limit at d 2.5 and 3, respectively. Also in this case, the microbial count for the 2 active samples ACT-COAT and ACT-COAT-GLY started to grow 1 and $2 \mathrm{~d}$ later with respect to the COAT and CNT samples. The gap between the 2 active samples in reaching the $\mathrm{MAL}^{\text {Pseudomonas }}$ was more evident during this second trial; in fact, ACT-COAT sample matched the limit at d 4.5, whereas ACT-COAT-GLY sample overlapped the microbial limit at d 6.2 and then $1.7 \mathrm{~d}$ later with respect to the ACT-COAT and more than 3 d later with respect to the CNT and COAT samples. Making a comparison between the 2 trials, we can say that the addition of the $L$. reuteri with glycerol to the alginate solution improves the microbiological quality but, allowing the microorganism to ferment the solution for $48 \mathrm{~h}$, further improves the result. The delay in reaching the MAL in the 2 active samples (ACT-COAT and ACT-COAT-GLY) may be explained by the presence of the active coating on the product surface. The addition of $L$. reuteri exerted a sort of antimicrobial action, probably due to the acidification of the substrate and the production of some metabolites such as organic acids and bacteriocins (Angiolillo et al., 2013). The combination of the microbial strain with glycerol extended the microbial quality because it has been demonstrated that this probiotic microorganism produces the antimicrobial component reuterin as an intermediate metabolite during the anaerobic fermentation of glycerol (Rasch et al., 2002). Therefore, allowing the microorganism to ferment the active solution for $48 \mathrm{~h}$ further improved the microbial quality of Fior di Latte samples because the microorganism produced reuterin.

These findings were also confirmed by the enumeration of lactic acid bacteria (data not shown) in the filmmaking solution after $48 \mathrm{~h}$ fermentation. Lactobacillus reuteri dry powder had a load of $9.21 \log \mathrm{cfu} / \mathrm{g}$. The lactic acid bacteria count in the active sodium alginate solution (with L. reuteri and glycerol) was $7.52 \mathrm{log}$ $\mathrm{cfu} / \mathrm{g}$, after 48-h fermentation no lactic acid bacteria were enumerated in the same alginate solution, proving that probably the fermentation process was effective in the production of reuterin but at the same time this antimicrobial component was lethal for the survival of the lactic acid bacteria population.

A reduction of $\mathrm{pH}$ value was recorded for both trials in the brine liquid (data not shown), and this is a common observation in dairy products enriched with 

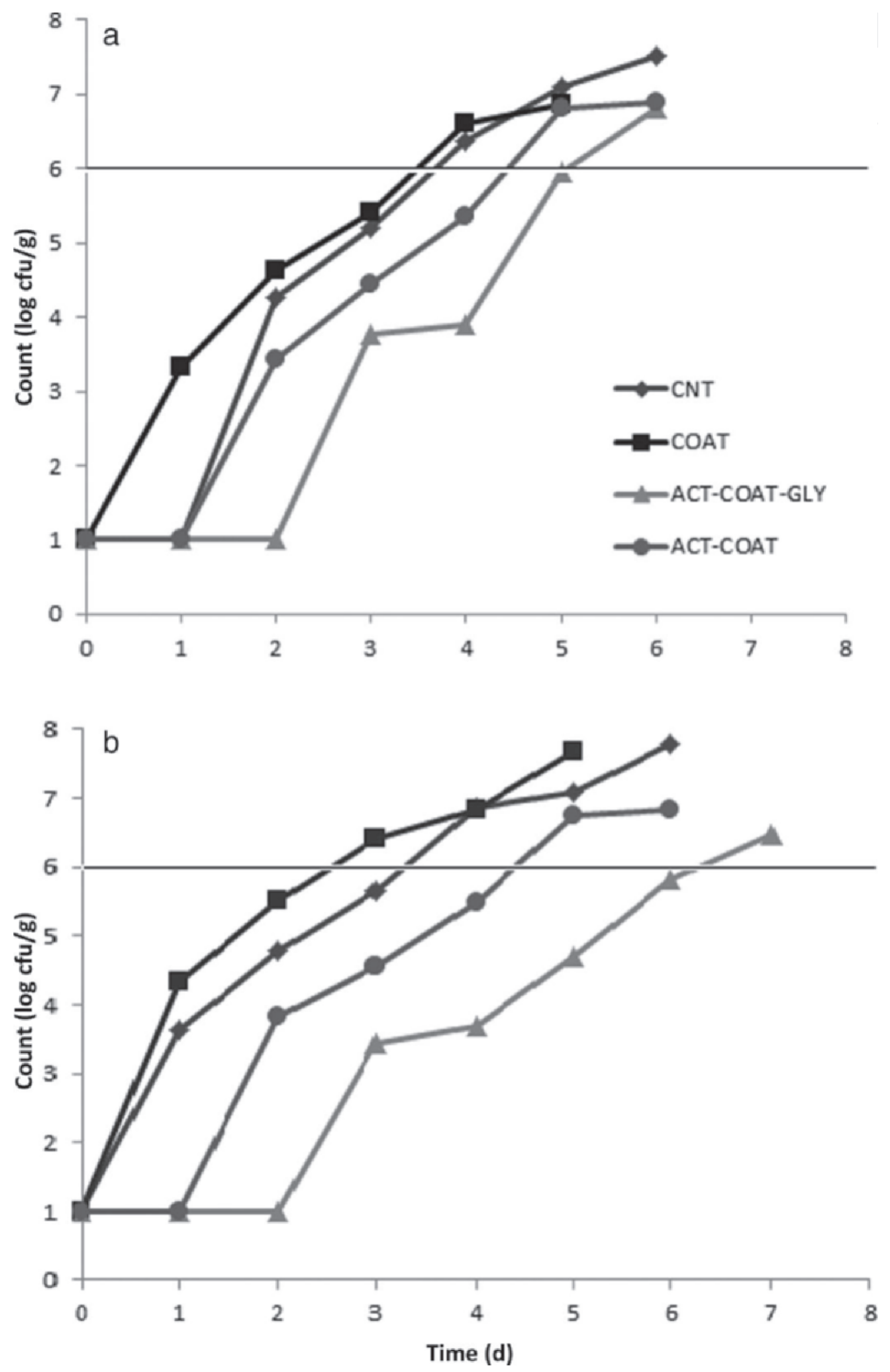

Figure 1. Evolution of Pseudomonas spp. count in Fior di Latte cheese during the 2 experimental trials: without fermentation of the active sodium alginate solution (a), with a fermentation period of $48 \mathrm{~h}$ at $25^{\circ} \mathrm{C}$ of the active sodium alginate solution (b). CNT $=$ control sample consisting of Fior di Latte cheese without coating; COAT = Fior di Latte cheese with a $2 \%$ sodium alginate coating without Lactobacillus reuteri; ACT-COAT-GLY $=$ Fior di Latte cheese with a $2 \%$ sodium alginate coating containing $L$. reuteri and glycerol; ACT-COAT $=$ Fior di Latte cheese with a $2 \%$ sodium alginate coating containing L. reuteri. 
probiotics because of the continuous production of organic acids that lower the $\mathrm{pH}$ of the environment and consequently inhibit bacterial pathogens growth (Pithava et al., 2011).

Figure 2 shows the evolution of Enterobacteriaceae population in Fior di Latte cheese during the 2 experimental trials: the first (a) and the second (b). Also for this microbial group, the addition of probiotic and its combination with glycerol in the coating proved to be effective in slowing down bacterial count in the final product. In Figure 2(a) the microbial group immediately increased for the COAT sample, whereas for the CNT sample, the increase was from $\mathrm{d} 2$. These 2 samples reached the acceptability limit (MAL $\left.{ }^{\text {Enterobacteriaceae }}\right)$ at d 3.5 and 5, respectively, whereas for the 2 active samples, the microbial population started to grow at d 2 for ACT-COAT and at d 3 for the ACT-COAT-GLY sample. The 2 active samples matched the microbial limit at d 6 and so later with respect to COAT and CNT samples. In the second trial (b), the 48-h fermentation of active alginate solution proved to be effective in slowing down the microbial deterioration, in fact in this case, COAT and CNT samples reached the microbial limit together at $\mathrm{d} 4.5$ and the ACT-COAT at $\mathrm{d}$ 5.3. On the contrary, the ACT-COAT-GLY sample started to deteriorate $1 \mathrm{~d}$ later with respect to the active sample without glycerol (ACT-COAT) and $3 \mathrm{~d}$ later with respect to samples without any active addition (COAT and CNT), overlapping the microbial limit at d 7. Also in this case the combination of the probiotic microorganism with glycerol improved the microbial quality, and the 48-h fermentation of the alginate solution further prolonged the microbial quality by $1 \mathrm{~d}$ with respect to the first trial. It can be suggested, on the basis of the microbial considerations, that the addition of probiotic and its combination with glycerol in the coating surface of the Fior di Latte cheese is an optimal and innovative way to preserve the product and at the same time, with a combination of an optimal fermentation time of the active alginate solution, to guarantee a significant microbial control.

\section{Sensory Quality}

Edible films and coatings are usually consumed with the coated product. Therefore, the incorporation of compounds such as probiotics should not affect consumer acceptance. The addition of probiotics to obtain antimicrobial edible films and the effect of this addition to the food product has been barely studied (RojasGrau et al., 2009). The taste of these nutraceutical ingredients has been regarded as a particularly important factor; several authors found that probiotics cause the acidification of the substrate and the production of some metabolites such as organic acids and bacteriocins (Pithava et al., 2011). Furthermore, the increase of fermentation processes can also lead to a change in the product structure. Fior di Latte cheese is considered a traditional Italian product with a characteristic sensory property that lends this product to the concept of "natural-traditional-product." Thus, it is necessary to preserve these attributes also when probiotic, prebiotic, or both are added. It is important that treatments applied to functionalize also maintain the appearance (i.e., color and integrity) and the flavor characteristics, being the first factors that the consumer perceives as product quality (Faccia et al., 2013). Figure 3 shows the evolution during storage of the overall quality of Fior di Latte cheese during the 2 experimental trials: without fermentation (a) and with a fermentation of $48 \mathrm{~h}$ (b). The curves were obtained by fitting Equation (2) to the experimental data, whereas the horizontal dashed line is the sensory threshold. In the first trial (a), overall quality steadily decreased in a more pronounced way in the COAT samples, which matched the sensory acceptability limit $\left(\mathbf{S A L}^{\mathbf{O Q}}\right)$ at $\mathrm{d}$ 6, whereas $\mathrm{CNT}$ and ACT-COAT samples reached the limit both at $d 7$. Sample ACT-COAT-GLY did not match the threshold for the entire observation period, and for this reason the $\mathrm{SAL}^{\mathrm{OQ}}$ was set $>7 \mathrm{~d}$ (Table 1 ). The same trend was observed in the second trial (b), with the only difference that the ACT-COAT sample in this case recorded the same overall quality trend of the ACT-COAT-GLY, probably due to the fact that the fermentation time allowed the microorganism to increase its fermentative action, contributing to improve the microbial quality and, as a consequence, also the sensory quality of the final product. The trend of the overall quality coincided with that of the odor (Figure 4), thus proving that this attribute represented the factor limiting cheese storability. Texture and color (Figure 4) attributes did not affect the overall quality of the product; indeed, the panelists expressed their judgments with a score above the acceptability limit during the entire storage time. The panelists highlighted a typical milk odor of samples coated with probiotic (ACT-COAT and ACT-COAT-GLY), which coincided with the natural characteristics of this Italian traditional product. This consideration probably determined the higher SAL ${ }^{\mathrm{OQ}}$ for the 2 active coated samples. A study conducted by Mirzaei et al. (2012) confirmed that the addition of free or encapsulated probiotics had no significant effect on sensory properties of a probiotic Iranian cheese, in fact the total evaluation in terms of color, texture, and taste of samples was good and did not have any marked off-flavor during the storage and samples enriched with probiotics recorded an overall quality better than that 

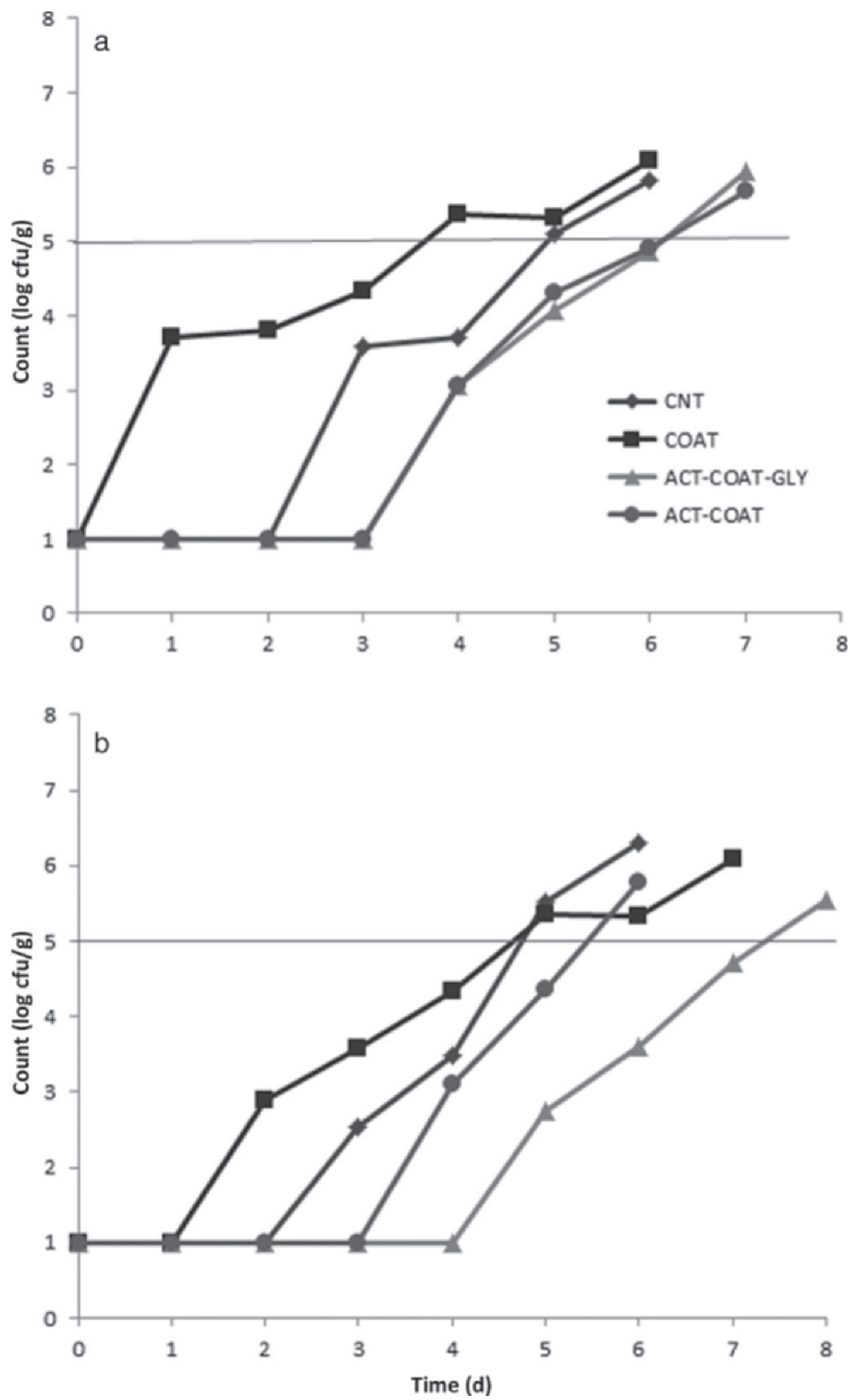

Figure 2. Evolution of Enterobacteriaceae count in Fior di Latte cheese during the 2 experimental trials: without fermentation of the active sodium alginate solution (a), with a fermentation period of $48 \mathrm{~h}$ at $25^{\circ} \mathrm{C}$ of the active sodium alginate solution (b). CNT $=$ control sample consisting of Fior di Latte cheese without coating; COAT = Fior di Latte cheese with a $2 \%$ sodium alginate coating without Lactobacillus reuteri; ACT-COAT-GLY $=$ Fior di Latte cheese with a $2 \%$ sodium alginate coating containing $L$. reuteri and glycerol; ACT-COAT $=$ Fior di Latte cheese with a $2 \%$ sodium alginate coating containing $L$. reuteri. 

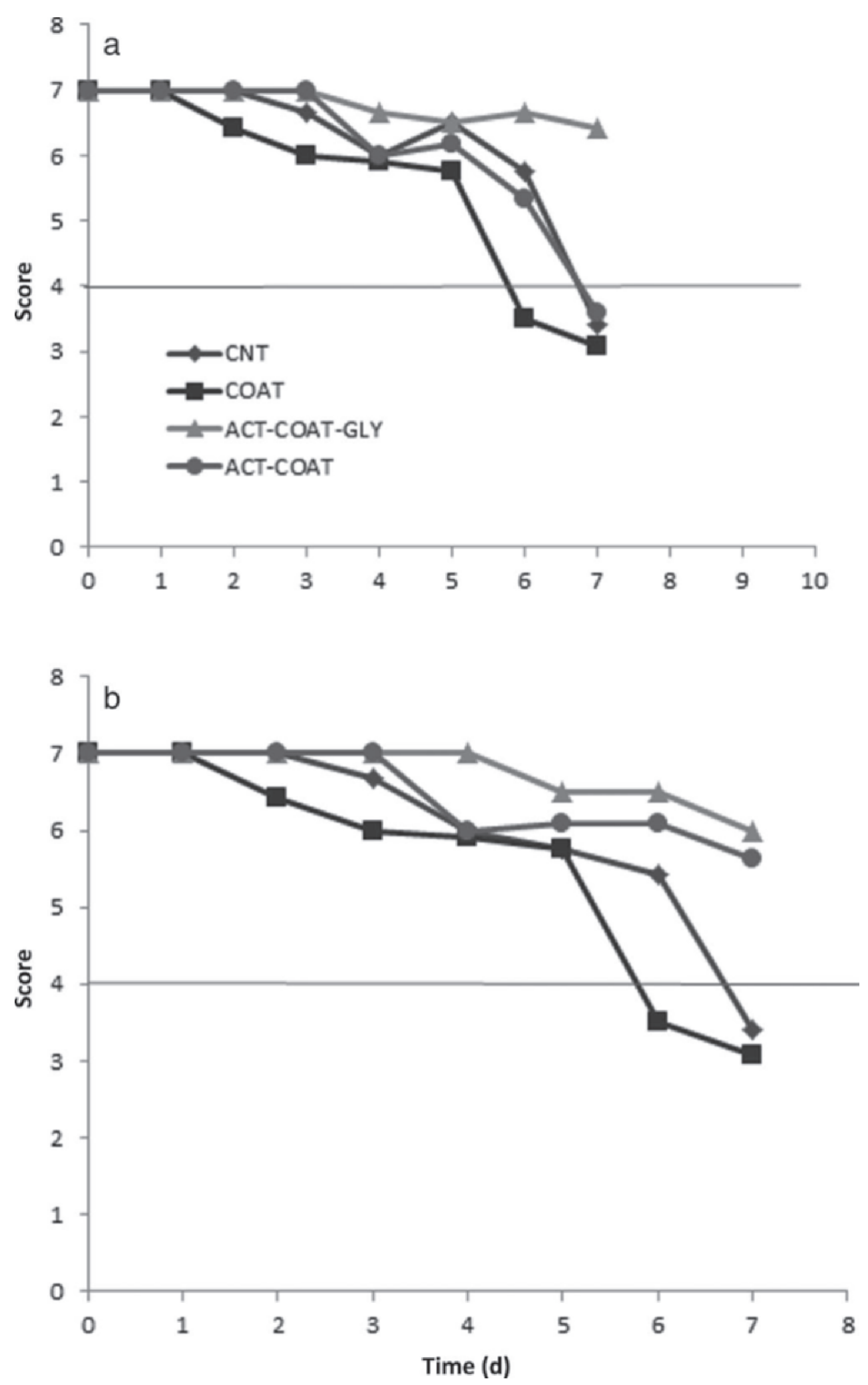

Figure 3. Evolution of the overall quality in Fior di Latte cheese during the 2 experimental trials: without fermentation of the active sodium alginate solution (a), with a fermentation period of $48 \mathrm{~h}$ at $25^{\circ} \mathrm{C}$ of the active sodium alginate solution (b). CNT $=$ control sample consisting of Fior di Latte cheese without coating; COAT = Fior di Latte cheese with a $2 \%$ sodium alginate coating without Lactobacillus reuteri; ACTCOAT-GLY $=$ Fior di Latte cheese with a $2 \%$ sodium alginate coating containing L. reuteri and glycerol; ACT-COAT $=$ Fior di Latte cheese with a $2 \%$ sodium alginate coating containing $L$. reuteri. 


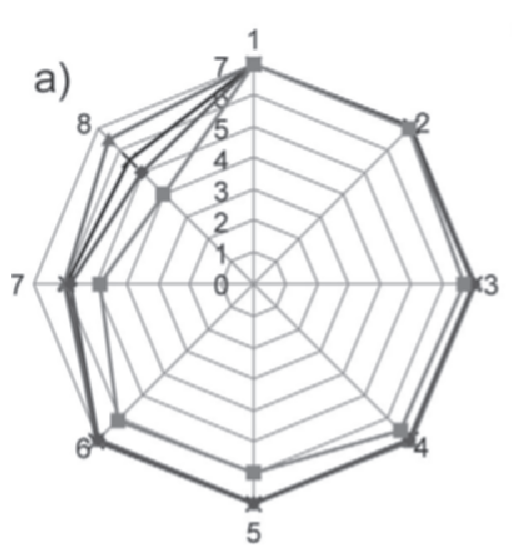

color
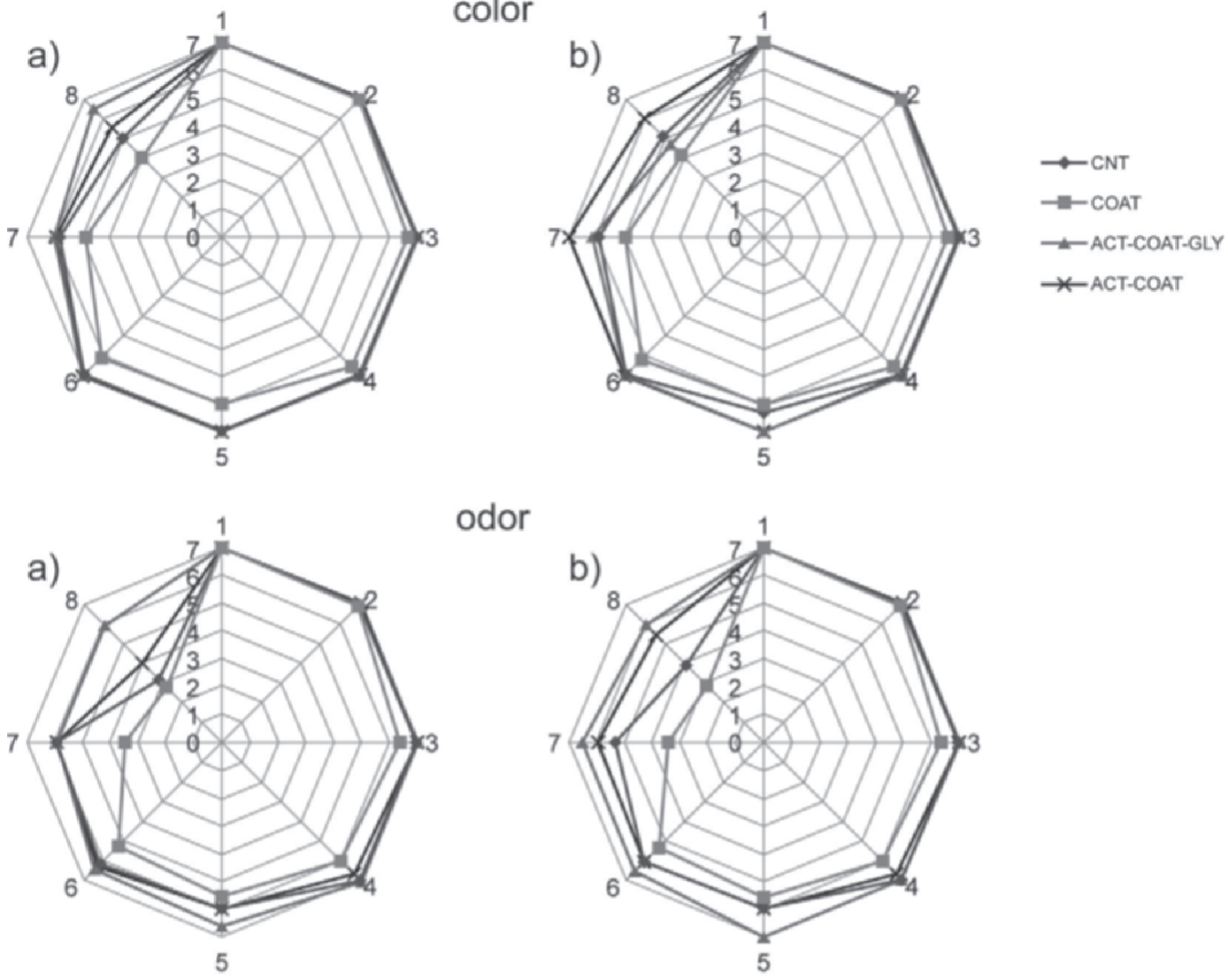

odor
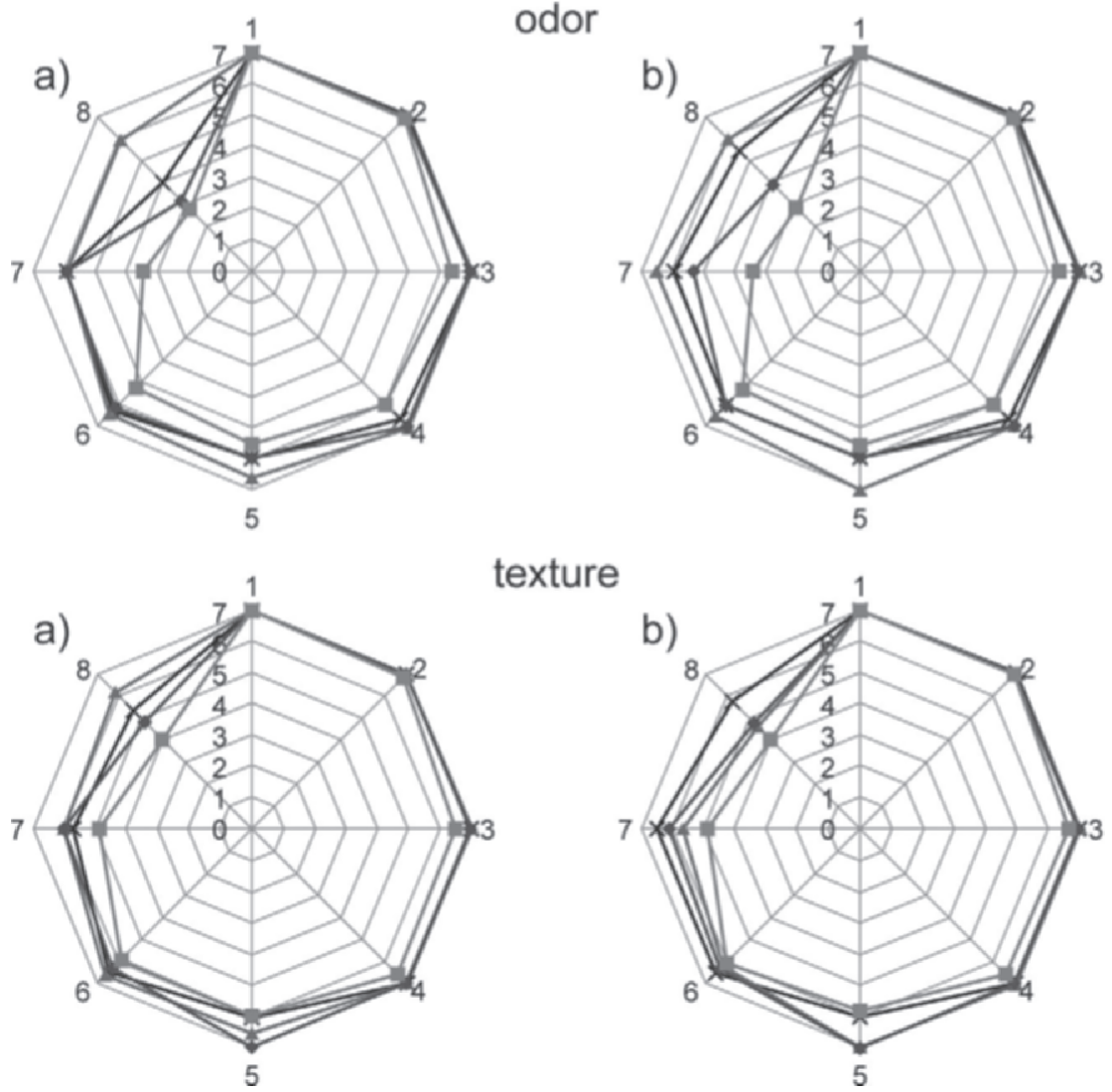

texture

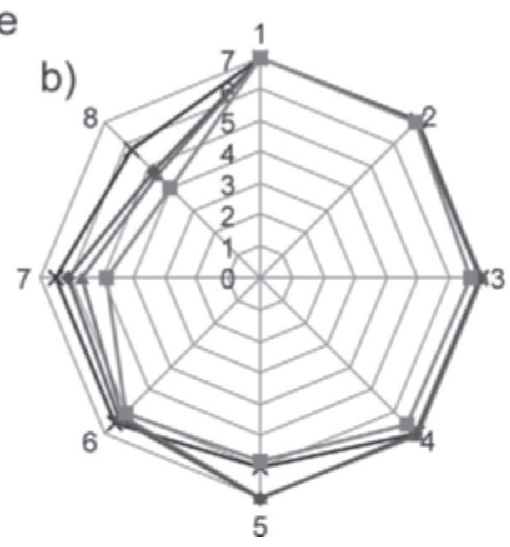

Figure 4. Evolution of odor, color, and texture in Fior di Latte cheese during the 2 experimental trials: without fermentation of the active sodium alginate solution (a), with a fermentation period of $48 \mathrm{~h}$ at $25^{\circ} \mathrm{C}$ of the active sodium alginate solution (b). CNT $=$ control sample consisting of Fior di Latte cheese without coating; COAT = Fior di Latte cheese with a $2 \%$ sodium alginate coating without Lactobacillus reuteri; ACT-COAT-GLY = Fior di Latte cheese with a $2 \%$ sodium alginate coating containing L. reuteri and glycerol; ACT-COAT = Fior di Latte cheese with a $2 \%$ sodium alginate coating containing $L$. reuteri.

with no probiotic cells. Therefore, sensory evaluation confirmed the considerations of the microbial quality: the use of $L$. reuteri into the sodium alginate solution was an active way to biopreserve the Fior di Latte cheese, and its combination with glycerol and with a 48-h fermentation time was more effective in slowing down the microbial deterioration and consequently improving the sensory properties.

\section{Shelf Life}

The Fior di Latte shelf life is listed in Table 1 for each sample tested in this study. It was calculated as the lowest value between MAL ${ }^{\text {Peeudomonas }}$, MAL ${ }^{\text {Enterobacteriaceae }}$, and $\mathrm{SAL}^{\mathrm{OQ}}$ (Conte et al., 2009). It can be emphasized from data that microbial quality limited the shelf life of the 3 samples, with a major contribution of Pseu- 
Table 1. Shelf life (days) of Fior di Latte samples as the lowest value between $\mathrm{MAL}^{\text {Pseudomonas }}, \mathrm{MAL}^{\text {Enterobacteriaceae }}$, and $\mathrm{SAL}^{1}$

\begin{tabular}{|c|c|c|c|c|}
\hline \multirow[b]{2}{*}{ Sample } & \multicolumn{2}{|c|}{ Microbial quality (d) } & \multirow{2}{*}{$\frac{\text { Sensory quality }(\mathrm{d})}{\mathrm{SAL}^{\mathrm{OQ}}}$} & \multirow[b]{2}{*}{ Shelf life (d) } \\
\hline & $\mathrm{MAL}^{\text {Pseudomonas }}$ & MAL $^{\text {Enterobacteriaceae }}$ & & \\
\hline \multicolumn{5}{|l|}{$9^{\circ} \mathrm{C}($ trial 1$)$} \\
\hline $\mathrm{CNT}^{2}$ & 3.5 & 5 & 7 & 3.5 \\
\hline $\mathrm{COAT}^{3}$ & 3.3 & 3.5 & 6 & 3.3 \\
\hline ACT-COAT-GLY ${ }^{4}$ & 5 & 6 & $>7$ & 5 \\
\hline $\mathrm{ACT}^{-\mathrm{COAT}^{5}}$ & 4.3 & 6 & 7 & 4.3 \\
\hline \multicolumn{5}{|l|}{$9^{\circ} \mathrm{C}($ trial 2) } \\
\hline CNT & 3 & 4.5 & 7 & 3 \\
\hline COAT & 2.5 & 4.5 & 6 & 2.5 \\
\hline ACT-COAT-GLY & 6.2 & 7 & $>7$ & 6.2 \\
\hline ACT-COAT & 4.5 & 5.3 & $>7$ & 4.5 \\
\hline
\end{tabular}

${ }^{1} \mathrm{MAL}=$ the microbiological acceptability limit; SAL $=$ the sensory acceptability limit; OQ = overall quality.

${ }^{2} \mathrm{CNT}=$ control sample consisting of Fior di Latte cheese without coating.

${ }^{3} \mathrm{COAT}=$ Fior di Latte cheese with a $2 \%$ sodium alginate coating without Lactobacillus reuteri.

${ }^{4} \mathrm{ACT}-\mathrm{COAT}-\mathrm{GLY}=$ Fior di Latte cheese with a $2 \%$ sodium alginate coating containing $L$. reuteri and glycerol.

${ }^{5} \mathrm{ACT}-\mathrm{COAT}=$ Fior di Latte cheese with a $2 \%$ sodium alginate coating containing $L$. reuteri.

domonas spp. growth. In the first trial (without any fermentation), the shelf life of CNT and COAT was set at $3.5 \mathrm{~d}$, whereas the 2 active sodium alginate-coated samples (ACT-COAT and ACT-COAT-GLY) revealed a longer storability, about 4.3 and $5 \mathrm{~d}$, respectively, probably for the improvement of the microbial and sensory characteristics of the active addiction. With the $48 \mathrm{~h}$ of microbial fermentation, both microbial and sensory quality further increased, in fact ACT-COATGLY shelf life was set at $6.2 \mathrm{~d}$ and then $1.2 \mathrm{~d}$ later with respect to the first trial. The shelf life for the CNT, COAT, and ACT-COAT samples was approximately equal to the first trial. To sum up, the application of an edible active sodium alginate coating enriched with L. reuteri and glycerol to Fior di Latte cheese improved its microbial and sensory characteristics, contributing to extend its shelf life.

\section{CONCLUSIONS}

In the first trial, the combination of the probiotic microorganism with glycerol (ACT-COAT-GLY) improved the microbial quality by $1 \mathrm{~d}$ compared with the same active solution without glycerol (ACT-COAT) and by about $1.5 \mathrm{~d}$ compared with the Fior di Latte sample without any active coating (CNT). The 48-h fermentation of the active alginate solution (second trial) further prolonged the microbial quality with respect to the first trial. In fact, in this case, COAT and CNT samples reached the microbial limit together at $\mathrm{d}$ 4.5, whereas the ACT-COAT at d 5.3. On the contrary, the ACT-COAT-GLY sample started to deteriorate $1 \mathrm{~d}$ later with respect to the active sample without glycerol (ACT-COAT) and $3 \mathrm{~d}$ later with respect to samples without any active addition (COAT and CNT), overlapping the microbial limit at $\mathrm{d} 7$. On the basis of the microbial considerations, the addition of probiotic and its combination with glycerol in the coating applied on Fior di Latte surface is an optimal and innovative way to biopreserve the product and at the same time, with a combination of an optimal fermentation time, to prolong its microbial quality. The sensory evaluation confirmed the considerations of the microbial quality; in fact, panelists highlighted a typical milk odor in the sample coated with probiotic (ACT-COAT and ACTCOAT-GLY), that promoted better scores for the 2 active coated samples. Therefore, the application of an active coating enriched with $L$. reuteri and glycerol to Fior di Latte cheese improved its microbial and sensory characteristics, contributing also to extend its shelf life.

\section{REFERENCES}

Ananou, S., M. Maqueda, M. Martínez-Bueno, and E. Valdivia. 2007. Biopreservation, an ecological approach to improve the safety and shelf-life of foods. Pages 30-33 in Communicating Current Research and Educational Topics and Trends in Applied Microbiology. A. Méndez-Vilas, ed. Formatex, Badajoz, Spain.

Angiolillo, L., A. Conte, M. Faccia, A. V. Zambrini, and M. A. Del Nobile. 2013. A new method to produce synbiotic Fiordilatte cheese. Innov. Food Sci. Emerg. Technol. 22:180-187.http:// dx.doi.org/ 10.1016/j.ifset.2013.09.010.

Arqués, J. L., E. Rodríguez, M. Nuñez, and M. Medina. 2008a. Inactivation of gram-negative pathogens in refrigerated milk by reuterin in combination with nisin or the lactoperoxidase system. Eur. Food Res. Technol. 227:77-82.

Arqués, J. L., E. Rodríguez, M. Nuñez, and M. Medina. 2008b. Antimicrobial activity of nisin, reuterin, and the lactoperoxidase system on Listeria monocytogenes and Staphylococcus aureus in cuajada, a semisolid dairy product manufactured in Spain. J. Dairy Sci. 91:70-75.

Bishop, J. R., and C. H. White. 1986. Assessment of dairy product quality and potential shelf life-A review. J. Food Prot. 49:739753 . 
Brody, A. L. 2001. Say cheese and package it, please! Food Technol. 55:76-77.

Chiavari, C., M. Nanni, G. Ferri, B. Morara, and G. Qualizza. 2006. Formare assaggiatori per la valutazione sensoriale della Mozzarella di bufala (Instructions for panelists to evaluate the sensory aspects of Buffalo Mozzarella cheese). Il Latte 11:66-70.

Conte, A., D. Gammariello, S. Di Giulio, M. Attanasio, and M. A. Del Nobile. 2009. Active coating and modified-atmosphere packaging to extend the shelf life of Fior di Latte cheese. J. Dairy Sci. 92:887-894.

Conte, A., C. Scrocco, M. Sinigaglia, and M. A. Del Nobile. 2007. Innovative active packaging system to prolong the shelf life of Mozzarella cheese. J. Dairy Sci. 90:2126-2131.

Del Nobile, M. A., D. Gammariello, A. Conte, and M. Attanasio. 2009. A combination of chitosan, coating and modified atmosphere packaging for prolonging Fior di Latte cheese shelf life. Carbohydr. Polym. 78:151-156.

Del Nobile, M. A., D. Gammariello, S. Di Giulio, and A. Conte. 2010. Active coating to prolong the shelf life of Fior di latte cheese. J. Dairy Res. 77:50-55.

Faccia, M., L. Angiolillo, M. Mastromatteo, and A. Conte. 2013. The effect of incorporating calcium lactate in the saline solution on improving the shelf life of Fiordilatte cheese. Int. J. Dairy Technol. 66:1-9.

Floros, J. D., P. V. Nielsen, and J. K. Farkas. 2000. Advances in modified atmosphere and active packaging with applications in the dairy industry. Packaging of milk products. Bull. Int. Dairy Fed. 346:22-28.

Gammariello, D., A. Conte, and M. A. Del Nobile. 2010. Assessment of chitosan and extracts of lemon and sage as natural antimicrobial agents during Fior di Latte cheesemaking. Int. J. Dairy Technol. 63:530-537.

Gammariello, D., S. Di Giulio, A. Conte, and M. A. Del Nobile. 2008. Effects of natural compounds of microbial safety and sensory quality of Fior di Latte cheese, a typical Italian cheese. J. Dairy Sci. 91:4138-4146.

Gill, A. O., P. Delaquis, P. Russo, and R. A. Holley. 2002. Evaluation of antilisterial action of cilantro oil on vacuum packed ham. Int. J. Food Microbiol. 73:83-92.

ISO (International Organization for Standardization). 1993. Sensory analysis - General guidance for the selection, training and monitoring of assessors-Part 1: Selected assessors. ISO 8586-1:1993. Accessed Mar. 13, 2013. http://www.iso.org/iso/catalogue_detail. htm?csnumber $=15875$.

ISO (International Organization for Standardization). 1994. Sensory analysis - General guidance for the selection, training and monitoring of assessors-Part 2: Experts. ISO 8586-2:1994. Accessed Mar. 13, 2013. http://www.iso.org/iso/iso_catalogue/ catalogue_ics/catalogue_detail_ics.htm? csnumber $=15876$.

Mirzaei, H., H. Pourjafar, and A. Homayouni. 2012. Effect of calcium alginate and resistant starch microencapsulation on the survival rate of Lactobacillus acidophilus La5 and sensory properties in Iranian white brined cheese. Food Chem. 132:1966-1970.

Pantaleao, I., M. M. E. Pintado, and M. F. F. Pocas. 2007. Evaluation of two packaging systems for regional cheese. Food Chem. 102:481-487.

Papaioannou, G., I. Chouliara, A. E. Karatapanis, M. G. Kontominas, and I. N. Savvaidis. 2007. Shelf-life of a Greek whey cheese under modified atmosphere packaging. Int. Dairy J. 17:358-364.

Pithava, S., P. Ambalam, J. M. Dave, and B. R. M. Vyas. 2011. Antimicrobial peptides of probiotic Lactobacillus strains. Pages 987991 in Science Against Microbial Pathogens: Communicating Current Research and Technological Advances. A. Mendez-Vilas, ed. Formatex, Badajoz, Spain.

Rasch, M., G. C. Barker, K. Sachau, M. Jakobsen, and N. Arneborg. 2002. Characterization and modelling of oscillatory behavior related to reuterin production by Lactobacillus reuteri. Int. J. Food Microbiol. 73:383-394.

Reuter, G. 2001. The Lactobacillus and Bifidobacterium microflora of the human intestine: Composition and succession. Curr. Issues Intest. Microbiol. 2:43-53.

Rodríguez, E., J. L. Arqués, R. Rodríguez, M. Nuñez, and M. Medina. 2003. Reuterin production by lactobacilli isolated from pig faeces and evaluation of probiotics traits. Lett. Appl. Microbiol. $37: 259-263$.

Rojas-Grau, M. A., R. Soliva-Fortuny, and O. M. Belloso. 2009. Edible coatings to incorporate active ingredients to fresh-cut fruits: A review. Trends Food Sci. Technol. 20:438-447.

Salvadori del Prato, O. 2001. Trattato di Tecnologia Casearia. Calderoni Ed. Agricole, Bologna, Italy.

Shelef, L. A. 1983. Antimicrobial effects of spices. J. Food Saf. 6:2944.

Spano, G., E. Goffredo, L. Beneduce, D. Tarantino, A. Dupuy, and S. Massa. 2003. Fate of Escherichia coli O157:H7 during the manufacture of Mozzarella cheese. Lett. Appl. Microbiol. 36:73-76.

Tassau, C., K. Koutsoumanis, and G. J. E. Nychas. 2000. Inhibition of Salmonella enteritidis and Staphylococcus aureus in nutrient broth by mint essential oil. Food Res. 33:273-280.

UNI (Ente Nazionale Italiano di Unificazione). 2003. UNI 10957:2003Analisi Sensoriale-Metodo per la definizione del profilo sensoriale degli alimenti e delle bevande. UNI, Milan, Italy.

Vollenweider, S., G. Grassi, I. König, and Z. Puhan. 2003. Purification and structural characterization of 3-hydroxypropionaldehyde and its derivates. J. Agric. Food Chem. 51:3287-3293.

Vollenweider, S., and C. Lacroix. 2004. 3-Hydroxypropionaldehyde: Applications and perspectives of biotechnological production. Appl. Microbiol. Biotechnol. 64:16-27.

Yousef, A. E., and C. Carlstrom. 2003. Page 226 in Food Microbiology: A Laboratory Manual. Wiley, Hoboken, NJ. 